\title{
Ethnic Club Cultures: Postmigrant Leisure SOCIALITIES AND MUSIC IN URBAN EUROPE ${ }^{1}$
}

\author{
Kira Kosnick
}

Over the past two decades, academic research on popular music has increasingly taken note of a newly emerging phenomenon linked to the emergence of new, transnational musical genres that are produced by the descendants of postcolonial and labour migrants to Western Europe. These genres, however, not only provide new listening experiences that draw upon hybrid musical influences, they also sustain particular leisure practices and nightlife socialities in Western Europe's metropolitan centres. In the following, I will present insights from an ERC research project that investigated these nightlife practices and socialities of migrant and ethnic minority youth over a period of four years.

In cities such as London, Paris and Berlin, thousands of young people with migrant backgrounds come together almost every day of the week for special club nights where they dance to Asian Kool, Bhangra beats, Zouk, Beur Rap music or Turkish Pop and Rock, among other genres. By focusing specifically on leisure practices in the context of postmigrant ${ }^{2}$ club scenes, we wanted to examine domains of social engagement that have so far mostly escaped the attention of researchers across the social sciences and

1 This study is based on the findings of a four-year research project $\gg$ New Migrant Socialities « that was funded by the European Research Council. The project was an attempt to develop a novel approach to the study of postmigrant and ethnic minority youth by looking at social practices and the emergence of new socialities in daily life contexts of public leisure. Our empirical starting point of investigation was nightlife, more specifically the postmigrant and ethnic minority club scenes that have emerged in major European cities over the past twenty years (Kosnick 2008 and 2015).

2 The term postmigrant has only recently gained currency in discussions on contemporary nation-states shaped by cross-border immigration. In relation to the descendants of migrants, the term allows to indicate the continued importance of transnational affiliations and cross-border orientations as well as migration histories in the lives of people who have not migrated themselves, without resorting to the problematic categories of second-, third- etc. generation immigrants or describing them simply as ethnic minorities. 
humanities. While youth researchers have noted that »clubbing constitutes the main leisure activity of young people in Europe's urban areas, the existence of club scenes for youth with migrant backgrounds has gone for the most part unnoticed (but see Boogaarts-de Bruin 2011; Huq 2002, 2006; Kim 2014). But, I would contend, these scenes offer an important chance to study new forms of urban sociality that postmigrant and ethnic minority youth produce and engage in. They also offer a chance to learn something about music, as music is of course a central feature of any club scene. But let me first say something about the study of ethnic minority youth across different disciplines.

There is a striking gap in the literature on ethnic minority and postmigrant youth when it comes to discussing what young people actually do, as opposed to how they identify. And this is partly due to a division of labour between quantitative, structural approaches and qualitative studies that focus on culture and cultural identity. I will briefly explain what I mean by this division of labour between structuralist and culturalist approaches to young people with migrant backgrounds.

\section{Structural Factors of Marginalization}

Concerns over growing economic deprivation and precarious work have prompted many studies on the consequences for young people with migrant backgrounds in Europe (Castel 1995; Mayer 2004; Wacquant 2007). Debates over a possible »second generation decline « (Gans 1992) or downward assimilation were quickly taken up in Europe in the mid-1990s, with researchers particularly interested in possible links between national integration policies and indicators of socio-economic integration (Crul/Vermeulen 2003; Portes/Rumbaut 2005). Levels of integration have been measured mostly by comparing quantitative information on educational performance, unemployment, crime levels and income statistics. The social lives of migrants have thus emerged primarily through the research prisms of conventional social institutions such as schooling (Eldering/Kloprogge 1989; Vermeulen/ Perlmann 2000), labour market (Muus 2002; Portes/Rumbaut 1996), family (Alba 2005; Nauck 2001), or »community« organizing on religious and ethnic grounds (Abbas 2006; Werbner/Modood 1997).

The prevalent focus on »structural « factors that are analyzed on the basis of quantitative data has consequences for the range and quality of social forms and practices that can appear as relevant to migrants' and postmigrants' lives. Practices that are not linked to formal institutions or leave 
traces that can be measured statistically by state agencies, academic or market surveys are less likely to receive research attention. So let me turn to the other side of the divide, the culturalist approach to migration, which is characterized by a concern with identity. It is here, of course, that music finds a place as well.

\section{The Culturalist Response: Migrant Identities}

What is often lost in the gap between quantitative indicators of the social on the one hand and cultural orientations on the other is the question of the social as lived practice. I would charge that even in the culturally oriented literature on migrants and their descendants in Europe, much effort has been spent on analyzing cultural identifications without paying equal attention to the complexity of social practices in which such identifications are embedded.

In the wake of a surging interest in »identity« issues across the social sciences and humanities, migrants and postmigrants have been intensely studied with regard to their identifications, attitudes and cultural orientations. While early research was interested in migrant identities mainly with regard to possible (segmented) assimilation or (multicultural) integration (Kymlicka 1995; Rex 1991; Soysal 1994; Taylor 1992), cross-disciplinary interest in newly emerging, »hybrid « and possibly transnational identities has increased over the past decade (e.g. Anthias 2001; Hall/Du Gay 1996; Back 1996; Moreiras 1999; Vertovec 2001; Werbner 2002). Drawing upon earlier work on situational ethnicities (Nagata 1974; Okamura 1981), as well as literary and postcolonial theory (Anzaldua 1987; Bhabha 1994), references to »hybrid« cultural production and identities abound in current literature on migrant youth.

But, I would argue, the de-essentialization that has taken place with regard to culture often does not extend to the analysis of migrant social forms and engagements, where the »community « concept still reigns supreme. Community often functions as a placeholder for »social group«, without actually examining the pertinence of its conceptual implications. This holds true even for recent cross-disciplinary approaches that advocate a hybrid or situational understanding of identity. Efforts to demonstrate the flexibility of cultural identifications are rarely linked to examining the dynamics of social practices. What we tried to do in our ERC project was to move beyond the theoretical, methodological and political impasse of culturalist identity politics on the one hand and structuralist assumptions pertaining to 
social segregation or disaffiliation on the other, by focusing on nightlife socialities.

What does this mean for ethnic club scenes and the music that matters in these scenes? As stated before, cities such as Berlin, London and Paris feature regular party nights that cater specifically to the tastes of young people with, for example, Turkish, Kurdish, South Asian, North African or Caribbean backgrounds. Thousands of young people gather not just on weekends in club venues to socialize and dance, and they form crowds that are not always ethnically exclusive, but in postmigrant scenes are usually dominated by a particular ethnic group. You will not find references to these events in »mainstream « city guides and listings but rather on Internet platforms such as asianclubguide.com, vaybee.de, or through mailing lists and social network sites. Often, events carve out special profiles and cater to more specific audiences among the ethnic target group, from professionals-only to student nights or queer nights.

Some of the musical genres that are part of these club cultures - Bhangra and Asian Underground, Dancehall or Raï - have received a lot of academic attention, particularly with regard to their culturally »hybrid « character. But, as with the more general paradigm shift towards the theorization of hybridity as a process of cultural »intermixing « (Bhabha 1994; Nghi $\mathrm{Ha}$ 2005; Hutnyk 2000), they tend to be heavily focused on questions of identity and cultural expression, and not on sociality. For Britain (Back 1996; Dudrah 2002; Huq 2002; Sharma/Sharma/Hutnyk 1996), Germany (Bennett 1999; Burul 2003; Cheesman 1998; Kaya 2002; Soysal 1999) and France (Echchaibi 2001; Orlando 2003; Oscherwitz 2004), the music of ethnic minority youths is almost invariably described as an expressive channel and resource for identity construction (but see Çağlar 1998; Steyerl 2004). Most of these claims are based on an analysis of the music itself, on song lyrics, and on interviews with musicians who talk about their creative work.

The question I want to ask is: What can this tell us about the ways in which music is actually used, consumed, danced to and listened to in everyday life contexts by people who are not producers themselves? This is at least potentially quite a different issue. I was at a conference on Underground Music Scenes earlier this summer in Porto, and among the vast number of papers given there, I found almost no references to the social contexts in which music was listened to or danced to. Production contexts, yes - lots of interviews with musicians and producers, people who are undoubtedly very important in sustaining particular music scenes. But in club scenes, the DJ might be the only creative music producer who is actually 
present, and music might matter to audiences in very different ways than is assumed by their producers.

Very little is said in the literature that I have mentioned about the particular consumption contexts in which young people draw upon this and other music in their daily lives, and about how it fuels social encounters. This absence is often exacerbated by the methodological strategies of much research which tends to rely heavily on interviews and textual interpretation, without considering the day-to-day activities and settings in which music use is embedded. But ethnographic approaches show that to study such contexts of use can considerably complicate the picture painted of some of these musical cultures. If you investigate the context of clubbing for example, it quickly emerges that Turkish Hip-Hop is not the music of choice at Turkish club events in Germany, and that Asian club nights in London might play a mix of Garage and R\&B with a bit of Bhangra thrown in. So in our research, we shifted attention away from music as a context of cultural meaning production and focused instead on club contexts as social formations, on urban leisure socialities. We asked, what is the lure of ethnic club nights for migrant and postmigrant youth in European cities, what kinds of people use these scenes for social encounters, and what is it that they do there? This is not to say that music was irrelevant, but we aimed to contextualize music within contexts of use that were not primarily about music. Going out dancing is about engaging with music, but it is also very much about engaging with other people. So what kinds of social meeting places do club scenes offer?

Taking our inspiration from work that addresses urban public space as a productive meeting ground for strangers - not in the sense of racialized or ethnic Others, but strangers as people who are not personally known to each other (Amin 2012; Blum 2002; Sennett 1977) - we approached club scenes as part of an urban fabric of public conviviality, as sites where qualified forms of proximity and engagement with strangers are produced. All club scenes are in fact sites of encounter in which the co-presence of unknown people is actively sought out and managed - through projections of indifference or different forms of making contact (Kosnick 2012). Club scenes tend to work as semi-public formations that lack exclusive membership, yet are structured around taste and appearance, informal networks, and varyingly non-exclusive dimensions of class, sexual orientation, age, and ethnicity. In the mainstream cultural studies work on club cultures, they have been inscribed with images of transgression, freedom and liberation « (Rief 2009: 4), as social contexts that thrive on the promise of communitas. But few studies have examined if and how the promise of commu- 
nal experience translates across different club scenes, nightlife gatherings, and musical genres represented in them.

To young people with migrant backgrounds, ethnic club scenes might offer experiences of sociality that are at least potentially in contrast to forms of exclusion and boundary-drawing experienced in other areas of their lives. Rather than simply offering opportunities to »be among themselves «, club scenes enable qualified encounters with strangers, as I said. These encounters might hold a different relevance for minorities racialized in the context of dominant public spheres than for racially or ethnically (and sexually) invisible majorities (Warner 2002). Different from social categories that imply exclusive, continuous and sometimes inescapable membership - such as the community, the gang, the family, the banlieusards - club scenes tend to be based on selective association and imply different modes of chosen engagement. The exploration of such modes of engagement might show how young people with migrant backgrounds create new forms of sociality and develop distinctive ways of inhabiting and making use of European city spaces. It was this hypothesis that guided our collective research as we set out to investigate the dynamics of postmigrant clubbing in European cities.

What we found, and this is not surprising, was that the forms of discrimination and marginalization ethnic groups and particularly youth face in other parts of their lives, and in the cities they live in, has a lot to do with what clubbing means to them, and how they engage in nightlife. These are all dimensions that shape how young people can participate in nightlife. But in this particular context here I will bring the attention back to the question of music and identity.

\section{Music, Identity and Authenticity}

To some extent, of course, music was in all our scenes used to invoke certain cultural identities. But importantly, not just along ethnic and racialized lines. The invocations could be sexual, class-based, explicitly political and more. To give one example, to play music from Israel at a queer TurkishGerman Gayhane club night in Berlin was certainly a political statement. But if I tell you that the artist was Dana International, the transsexual singer who won the 1998 Eurovision Song Contest, those political dimensions reveal themselves to be both linked to challenging hetero-normative and gender-normative stereotypes. It was also linked to making a statement against anti-Semitism, the DJ told me, but you can see how different intersecting dimensions of political relevance come into play. Her song had 
quickly entered into the archives of international gay camp, and as such it could find its place in a medley of Turkish pop music mixed with other musical genres at a queer club night organized by and for people with backgrounds from Turkey in Berlin.

Many club nights and scenes we studied did not thrive on ethnically coded music as the central focus of identity production among audiences. British Asian club scenes in London, for example, particularly the heteronormative ones, did feature music such as Bhangra, which is very much an evolving transnational genre heavily influenced by migrants and postmigrants in the UK. But very often, British Asian club nights would incorporate lots of US Hip-Hop and contemporary R'n'B, and music featured very rarely in our informants' conversations when deciding where to go out to. Instead, the location and style of a venue were crucial, and of course the fact that the party event addressed British Asians as the target audience. You can see this when looking at the promotional material of one of the club organizers we followed, an organization called Voodoo Entertainment which specialized in upscale British Asian parties.

The following promotional text went with a flyer for a party event called »Elegance « at club Divo in London:

»Voodoo Entertainment invite you to an exclusive one off night in the heart of central London which boasts Glamour, Sophistication and Elegance. Divo is the latest addition to London's nightclub scene and is a luxurious Mansion style club with 18th Century Baroque Style furniture and crystal chandeliers.

Naming your venue amazing (Divo in Ukrainian) is a bold statement and Divo promises nothing less than an amazing setting that will simply take your breath away. Divo offers a truly unique, >millionaires club< style atmosphere and is a magnificent bar/club with opulent décor. In this exclusive setting, a warm and intimate feel radiates throughout and an excellent standard of service is provided to complement the lush interior.

Rich with style and elegance, oak floors and high ceilings are primary features, whilst in the basement there is an amazing Palekh style bar. We have lost count of the number of Footballers, TV stars and celebrity DJs that have appeared at this club recently. Voodoo Entertainment opens the doors to the hottest venues and offers our members invitations to some of the most talked about parties in town and this one is certainly not one to be missed! DJs shall be mixing up sexy beats across all genres as we come together to celebrate \& party. $\ll^{3}$

3 Flyer promoting an event on Saturday, 22nd May 2010. Text and cover design at http://www.chillitickets.com/9492-elegance-and (last access 14.5.2015). 
Voodoo events rarely mention music or specific DJs as a point of attraction; instead, the attention is primarily on elements of class distinction. This is not atypical for London clubbing in general, where the combination of nightlife regulation, licensing and consumer demand tend to privilege clubbing for the rich and famous, as Phil Hadfield has shown (Hadfield 2008). Voodoo is only one of many British Asian party organizers, but one that successfully manages to play to the desires for class distinction and social mobility among young British Asians, as our researcher Harpreet Cholia shows in her work (Cholia 2012, 2013). Renting locations in the expensive centre of London is part of the package.

It was a very different situation in Paris where we looked at French Caribbean clubbing events, many of which took place in the banlieues and catered to low-income black immigrants and postmigrants. Those gatherings were very much about ethnic identity, and about racialized identity as well. Almost all of the events celebrated some form of belonging to the French Caribbean Islands - that is to Guadeloupe or Martinique in particular. References to the Caribbean figured prominently on event flyers, showing for example women clad in bikinis, palm trees and beaches, with party events entitled »Back to the West Indies « and of course references to specific musical genres such as Zouk, to mention just a few typical features.

Even though many of the people who formed part of the audiences at these events had been born and raised in Paris, and all of them had French passports due to the status of the islands as overseas departments, they did not identify as French at all. What partially redeemed our white female researcher in the eyes of her black peer group and the audiences at these events was that she was Italian, and therefore not quite representing the white majority society in which they felt excluded, and from which they sought distance at these events. It also helped that she eventually managed to acceptably dance to Zouk.

Most of the time, club nights would feature Zouk as a genre of music crucially held to represent the French Caribbean, but often it would be combined with other musical genres of the Black Diaspora, most importantly dancehall, but also Hip-Hop, Salsa, Coupé Décalé, and Kuduro. So while musical influences could come from a variety of places, including African countries, the club events themselves were not necessarily welcoming people from all of those places, except maybe as artists. Door policies often actively excluded Africans, particularly African men, as our researcher Sabina Rossignoli witnessed many times. This contrasted with how people listened to and shared music, hardly ever buying it but sharing it on social networks and MSN messenger, listening and watching on YouTube. 
The importance of music to identity construction in this case is not so evident in the particular listening habits of audiences or even the playlists of clubs. There is a lot more to be learned about music and identity here if we shift our attention to dance, which is a practice that is facilitated by music but needs to be examined in its own right. Here is another example of what can be learned when contextualizing music socially and looking more closely at how it is used and made sense of in particular contexts. Because while people were listening to all kinds of music and dancing to all kinds of music in clubs, the relationship they had to Zouk was different.

Zouk is a couple dance that emerged in the French Caribbean in the 1980 s, and like no other genre it is seen by club audiences to symbolize the culture of the Islands. And to demonstrate one's natural belonging to the Islands, one had to be able to dance well to Zouk, not as an acquired skill, but as something that comes naturally to »true « Antilleans.

The following is a quote from Sabina Rossignoli's unpublished PhD thesis:

»To some extent, the competence in zouk was not taken as a form of literacy: every time I asked my informants to explain some steps and figures of the dance to me, they told me they did not know. They did not have memories of having learned the dance, as most of them had taken part in social dances from an early age. For the ones who did not, dancing was a source of stress in these nights where zouk has such a degree of importance... The weight of judgment was important in this scene, and people were anxious about being seen and being judged not able to dance. Franciane told me that she learned new steps exclusively in the intimacy of her bedroom, as she was scared of people thinking that she was not able to dance: >If you get the step wrong, it is shameful: people would say: >Look at this girl, she dances badly« (15/10/ 2010). This uncertainty was crucial to the experience of clubbers, who never admitted that they looked at others in order to learn, nor that they themselves might have been mediocre dancers. The way they intended zouk was as the cultural capital that distinguished them as a group; through zouk, the >community < of nightlife felt as the Antillean >community« (Rossignoli 2013: 225f.).

For the peer group that Sabina was able to connect and go out with, Zouk competence had to be demonstrated but not acquired in clubs. It was fine for them to learn and try out new steps to dance to other music genres in a club, but not for Zouk. So a lot of rehearsing for dancing on the public stage of the club would take place privately, by watching YouTube videos and trying out the steps at home. Dancing in the club was then again about demonstrating a competence that was presented as natural, and thereby proving oneself to truly belong to the Islands. 
In the wider context of our fieldwork, the heteronormative French Caribbean club scene in Paris was actually the only situation in which clubbing was so oriented toward celebrating and simultaneously constructing diasporic belonging. In British Asian club scenes in London, people from India or Pakistan who came to club nights were even referred to as spendus «, a derogatory term that implies that someone is uneducated, a simpleminded villager, unless they were upper-class. Other identity dimensions were often much more crucial than diasporic connections, as I have shown with a few examples from our fieldwork. Regardless of what they are, I hope that I have been able to show that by focusing on concrete social contexts in which music can be embedded, such as clubbing, it is possible to gain new insights into the connections between music, identity and social practice.

\section{Bibliography}

Abbas, Tahir (2006). Muslim Britain. Communities under Pressure. London: Zed Books.

Alba, Richard (2005). »Bright vs. Blurred Boundaries: Second-Generation Assimilation and Exclusion in France, Germany, and the United States. «In: Ethnic and Racial Studies 28:1, pp. 20-49.

Amin, Ash (2012). Land of Strangers. Cambridge: Polity Press.

Anthias, Floya (2001). »New Hybridities, Old Concepts: the Limits of >Culture «« In: Ethnic and Racial Studies 24:4, pp. 619-641.

Anzaldua, Gloria (1987). Borderlands/La Frontera: The New Mestiza. San Francisco: Aunt Lute.

Back, Les (1996). New Ethnicities and Urban Culture: Racims and Multiculture in Young Lives. London: Routledge.

Bennett, Andy (1999). »Hip hop am Main: The Localization of Rap Music and Hip hop Culture. «In: Media, Culture \& Society 21:1, pp. 77-91.

Bhabha, Homi K. (1994). The Location of Culture. London, New York: Routledge.

Blum, Alan (2001). »Scenes. «In: Public 22/23, pp. 7-35.

Boogaarts-de Bruin, Simone (2011). Something for Everyone? Changes and Choices in the Ethno-Party Scene in Urban Nightlife. Amsterdam: University of Amsterdam Press.

Burul, Yesim (2003). »The World of Aziza A.: Third Spaces in Identities. «In: New Perspectives on Turkey 28/29, pp. 209-228.

Çağlar, Ayșe (1998). »Verordnete Rebellion. Deutsch-türkischer Rap und türkischer Pop in Berlin. "In: Globalkolorit: Multikulturalismus und Populärkultur. Ed. by Ruth Mayer and Mark Terkessidis. St. Andrä/Wördern: Hannibal, pp. 41-56.

Castel, Robert (2000). Die Metamorphosen der sozialen Frage. Eine Chronik der Lohnarbeit. Konstanz: UVK.

Cheesman, Tom (1998). »Polyglot Politics. Hip Hop in Germany.«In: Debatte 6:2, pp. 191-214. 
Cholia, Harpreet (2012). » This is where it's at! Moving On Up... and Around the City. A Journey Through the British Asian Club Scenes in London. In: Jahrbuch für Europäische Ethnologie. Großbritannien. Dritte Folge 7. Ed. by Heidrun Alzheimer, Sabine Doering-Manteuffel, Daniel Drascek and Angela Treiber. Paderborn: Schöningh, pp. 89-100.

Cholia, Harpreet (2013). » The Dancing Diaspora<. Von Frankfurt nach London: Südasiatische Clubszenen in europäischen Städten. «In: India Magazin, January, p. 70; http://www.migrant-socialities.de/fileadmin/redaktion/PDF/Artikel_Cholia _India_Magazin_Jan2013.pdf (last access 15.5.2015).

Crul, Maurice / Vermeulen, Hans (2003). »The Second Generation in Europe. In: International Migration Review 37:4, pp. 965-986.

Dudrah, Rajinder K. (2002). »Drum'n'dhol.«In: European Journal of Cultural Studies 5:3, pp. 363-383.

Echchaibi, Nabil (2001). "We are French too, but Different: Radio, Music and the Articulation of Difference Among Young North Africans in France.« In: International Communication Gazette 36:4, pp. 295-310.

Eldering, Lotty / Kloprogge, Jo (1989). Different Cultures Same Schools. Ethnic Minority Children in Europe. Amsterdam: Swets \& Zeitlinger.

Gans, Herbert J. (1992). "Second-Generation Decline: Scenarios for the Economic and Ethnic Futures of the Post-1965 American Immigrants. «In: Ethnic and Racial Studies 15:2, pp. 173-192.

Hadfield, Phil (2008). »From Threat to Promise. Nightclub sSecurity<, Governance and Consumer Elites. «In: British Journal of Criminology 48, pp. 429-447.

Hall, Stuart / Du Gay, Paul (eds.) (1996). Questions of Cultural Identity. London: Sage.

Huq, Rupa (2002). »European Youth Cultures in a Post-Colonial World.« In: Migration 39/40/41, pp. 195-213.

Huq, Rupa (2006). Beyond Subculture: Youth, Pop and Identity in a Post-Colonial World. London: Routledge.

Hutnyk, John (2000). Critique of Exotica: Music, Politics and the Culture Industry. London: Pluto Press.

Kaya, Ayhan (2002). »Aesthetics of Diaspora: Contemporary Minstrels in Turkish Berlin. «In: Journal of Ethnic and Migration Studies 28:1, pp. 43-62.

Kim, Helen (2014). » No Caps, no Coconuts, no All-Male Groups ....The Regulation of Asians in London Clubs. "In: Ethnic and Racial Studies 37:4, pp. 636-651.

Kosnick, Kira (2008). »Out on the Scene: Queer Migrant Clubbing and Urban Diversity.«In: Ethnologia Europaea 38:2, pp. 19-30.

Kosnick, Kira (2012). »Utopien des Sozialen. Das Nachtleben als Sozialisationsinstanz und Spiegel von Gesellschaft. «Paper held at 1. Nationale Tagung Safer Nightlife Schweiz Nachtleben: Spass und Risiko - lebendige Stadt oder öffentliches Ärgernis?, September, Biel; http://www.migrant-socialities.de/fileadmin /redaktion/PDF/Kosnick_SNS_2012_Vortrag_Safer_Nightlife_Biel.pdf (last access 15.5.2015).

Kosnick, Kira (ed.) (2015). Postmigrant Club Cultures in Urban Europe. Frankfurt/M.: Peter Lang.

Kymlicka, Will (1995). Multicultural Citizenship. A Liberal Theory of Minority Rights. Oxford: Oxford University Press.

Mayer, Margit (2004). »The Onward Sweep of Social Capital: Causes and Consequences for Understanding of Cities, Communities and Urban Movements. «In: International Journal of Urban and Regional Research 27:1, pp. 110-132. 
Moreiras, Alberto (1999). »Hybridity and Double Consciousness." In: Cultural Studies 13:3, pp. 373-407.

Muus, Philip (2002). Migration and Immigrant Policy, Immigrants from Turkey and their Participation in the Labour Market: An International Comparison. Utrecht: ERCOMER.

Nagata, Judith (1974). »What is a Malay? Situational Selection of Ethnic Identity in a Plural Society.« In: American Ethnologist 1:2, pp. 331-350.

Nauck, Bernhard (2001). »Intercultural Contact and Intergenerational Transmission in Immigrant Families. «In: Journal of Cross-Cultural Psychology 32:2, pp. 159173.

Nghi Ha, Kien (2005). Hype um Hybridität. Kultureller Differenzkonsum und postmoderne Verwertungstechniken im Spätkapitalismus. Bielefeld: transcript.

Okamura, Jonathan Y. (1981). »Situational Ethnicity.« In: Ethnic and Racial Studies 4:4, pp. 452-465.

Orlando, Valérie (2003). »From Rap to Raï in the Mixing Bowl: Beur Hip-Hop Culture and Banlieue Cinema in Urban France. « In: Journal of Popular Culture 36:3, pp. 395-415.

Oscherwitz, Dayna L. (2004). »Pop goes the Banlieue: Musical Métissage and the Articulation of a Multiculturalist Vision. «In: Contemporary French and Francophone Studies 8:1, pp. 43-50.

Portes, Alejandro / Rumbaut, Ruben (1996). Immigrant America: A Portrait. Berkeley, CA: University of California Press.

Portes, Alejandro / Rumbaut, Ruben (2005). "The Second Generation and the Children of Immigrants Longitudinal Study. «In: Ethnic and Racial Studies 28:6, pp. 983-999.

Rex, John (1991). »The Political Sociology of a Multi-Cultural Society.«In: Journal of Intercultural Studies 2:1, pp. 7-19.

Rief, Silvia (2009). Club Cultures. Boundaries, Identities, and Otherness. New York: Routledge.

Rossignoli, Sabina (2013). Diasporic identification and gender construction in the Caribbean nightlife of Paris. Paris, Frankfurt/M.: Unpublished PhD Thesis [defended as a cotutelle thesis at Université Paris Descartes and Goethe-Universität Frankfurt am Main].

Sennett, Richard (1977). The Fall of Public Man. Cambridge: Cambridge University Press.

Sharma, Ashwani / Sharma, Sanjay / Hutnyk, John (eds.) (1996). Dis-Orienting Rhythms: The Politics of the New Asian Dance Music. London: Zed Books.

Soysal, Levent (1999). Projects of Culture: An Ethnographic Episode in the Life of Migrant Youth in Berlin. Cambridge, MA: Harvard University Press.

Soysal, Yasemin N. (1994). Limits of Citizenship: Migrants and Postnational Membership in Europe. Chicago: University of Chicago Press.

Steyerl, Hito (2004). "Gaps and Potentials: The Exhibition Heimat Kunst - Migrant Culture as an Allegory of the Global Market." In: New German Critique 92 (Spring/Summer), pp. 159-168.

Taylor, Charles (1992). Multiculturalism and >The Politics of Recognition<. Princeton: Princeton University Press.

Vermeulen, Hans / Perlmann, Joel (2000). Immigrants, Schooling and Social Mobility: Does Culture Make a Difference? Basingstoke: Macmillan.

Vertovec, Stephen (2001). »Transnationalism and Identity.«In: Journal of Ethnic and Migration Studies 27:4, pp. 573-582. 
Wacquant, Loïc (2007). »Territorial Stigmatization in the Age of Advanced Marginality. «In: Thesis Eleven 91 (November), pp. 66-77.

Warner, Michael (2002). »Publics and Counterpublics.«In: Public Culture 14:1, pp. 49-90.

Werbner, Pnina (2002). Imagined Diasporas among Manchester Muslims. Santa Fe, NM: SAR Press.

Werbner, Pnina / Modood, Tariq (1997). Debating Cultural Hybridity: Multi-Cultural Identities and the Politics of Anti-Racism. London: Zed Books.

\begin{abstract}
New transnational musical genres produced by migrants and their descendants to Western Europe have contributed to the emergence of ethnic club cultures in European metropolitan centers. The text presents insights from an ethnographic research project that investigated the cultural and social dynamics of ethnic club scenes in London, Paris and Berlin. Providing examples from British Asian clubbing contexts in London and French Caribbean scenes in Paris, it is shown how a focus on the practical uses of music in the context of clubbing can reveal new insights into the link between music, identity and ideas of cultural authenticity.
\end{abstract}

